\title{
The Power of Myth: A Case for A Woman Pope
}

\author{
Frank Shapiro
}

Independent Researcher

\begin{tabular}{|c|c|}
\hline ARTICLE INFO & ABSTRACT \\
\hline $\begin{array}{l}\text { Keywords: } \\
\text { Christianity } \\
\text { History } \\
\text { Mary Magdalene } \\
\text { Papacy } \\
\text { Church }\end{array}$ & $\begin{array}{l}\text { No matter how bizarre and unreal myths maybe they embody extraordinary } \\
\text { power and influence. Undoubtedly, myths also possess some measure of } \\
\text { historical authenticity. One of the first women in western history to be } \\
\text { cloaked in the mantle of fame and mystery was Mary Magdalene. She } \\
\text { emerges as a semi-mythical figure. However, judging by the spiritual } \\
\text { message of love she instils into the hearts of millions of Christian believers, } \\
\text { and by viewing the thousands of works of art evoking her supposed } \\
\text { attributes, deeds and influence, and in surveying the numerous churches, } \\
\text { convents and other religious orders erected in her honor as their patron saint, } \\
\text { one can say that her shadow bridges the divide between myth and history. } \\
\text { In my research I find it doubtful whether the disciples would have had the } \\
\text { courage to continue advancing the cause of Christianity without Mary. in } \\
\text { the wake of Christ's death, Christianity sank to its lowest point; and would } \\
\text { either have vanished or become just another marginal Jewish sect. It was } \\
\text { due to Mary's charisma and fortitude that empowered Christianity with the } \\
\text { tools to persevere. The Magdalene phenomenon lingered on as a growing } \\
\text { threat to the Church. How else can we explain the extreme measures the } \\
\text { Church eventually took in expunging her memory? Branding the } \\
\text { Magdalene myth with sin aided in negating the gender equality ethos of the } \\
\text { early apostolic church and justifying the authorization of the Petrus pope } \\
\text { dynasty. }\end{array}$ \\
\hline
\end{tabular}

\section{Introduction}

This paper proposes that Mary Magdalene's immense influence on western civilization is a case history for the power of myth. Had early apostolic Christianity taken a different path Magdalene could have triggered a female papacy. Judging by the spiritual message of love she has instilled into the hearts of millions of Christian believers, and by viewing the thousands of works of art evoking her supposed attributes, deeds and influence, and in surveying the numerous churches, convents and other religious institutions erected in her honor as their patron saint, one can say that Mary Magdalene's shadow bridges the divide between myth and history. The most predominate theme is that the cause of Christianity might have been lost had she not intervened in the early apostolic movement's darkest hours. As a redeemed sinner, she became the embodiment of hope and love for millions of people. Throughout the ages, her charisma and the values she upheld inspired the world of art to project her power.

\section{Findings}

The early apostolic sources pinpoint Mary Magdalene as one of the earliest woman activists practicing gender equality and highlighting women's rights. ${ }^{1}$ And this took place within the

\footnotetext{
${ }^{1}$ Regarding gender equality in the Early Apostolic Church see for example: Paul's letters: Phil.4.2; Rom.16, Mark 15-4-41; Mathew 27.55; Luke 8.1-3, John 4-9.27.
}

* Corresponding author E-mail address: fshap@013.net 
framework of the early apostolic church. The New Testament indicates that Jesus, head of the band of disciples, included among his followers a significant number of women: "And many women were there beholding afar off, which followed Jesus from Galilee, ministering unto him. Among which was Mary Magdalene, and Mary the mother of James and Joses, and the mother of Zebedee's children." . Other examples of women followers are Joanna, Susanna, and Martha and Mary of Bethany. However, chief among them was Mary Magdalene.

The Gospel of Mary indicates that Mary Magdalene and Jesus shared a definite intimacy, and this relationship seemed to have aroused jealousy among some of the other Apostles, for we read thus:

Then Andrew began to speak, and said to his brothers:

'Tell me, what do you think of these things she has been telling us?

As for me, I do not believe

that the Teacher would speak like this.

These ideas are too different from those we have known.'

And Peter added:

'How is it possible that the Teacher talked

in this manner, with a woman,

about the secrets of which we ourselves are ignorant?

Must we change our customs,

and listen to this woman?

Did he really choose her, and prefer her to us?'2

From this excerpt we can also gather the growing animosity of Peter towards Mary. There was certainly a strong case for Peter's dislike, and even growing envy of Mary. This we can discern as the story of Christ unfolds.

While Mary proves to be far more valiant than Peter in maintaining her faith in Jesus, Peter denies Christ three times ${ }^{3}$. Also, Jesus displays animosity toward Peter when the latter discounts Jesus' prophecy of the days to come leading to his crucifixion: “...he rebuked Peter, saying, Get thee behind me, Satan: for thou savourest not the things of that be of God, but the things that be of men." 4 . Furthermore, when Christ's followers panicked and abandoned him from the moment of his capture by the Romans and up to his crucifixion, Mary Magdalene stayed at his side weeping at the foot of the cross during Christ's Agony. During his ordeal on the cross it was Mary Magdalene who had the courage to stay with him up to his last moments. Mary Magdalene's fortitude never weakened: she stayed put throughout his agonies, while the other apostles and disciples fled. Fear of the authorities seems to have overclouded their belief and ideals.

Mary Magdalene helped to take down Jesus' body from the cross and lay it in the tomb prepared by Joseph of Arimathea. Mary's sincerity and attachment to Jesus knew no bounds. At dawn she went to his tomb together with Mary Salome and Mary the mother, bringing with them sweet spices to anoint his body. And it was then that they discovered that the tomb was empty. Soon afterwards, Mary witnessed the miracle of Jesus' resurrection. This event of her encounter with the resurrected Jesus on the third day after his execution led to Mary's eternal fame. "Now when Jesus was risen early the first day of the week, he appeared first to Mary Magdalene" 5 . The account in Mathew is slightly different from that in the other Gospels, in that Mary Magdalene together with another Mary encounter an angel at the sepulcher who instructs them

\footnotetext{
${ }^{1}$ Mathew Ch. 27 vs.55-56

${ }^{2}$ Gospel of Mary 17: 9-20

${ }^{3}$ Mathew Ch.26 vs 69-75 and Mark Ch.14 vs 66-72

${ }^{4}$ Mark Ch. 8 v 33

${ }^{5}$ Mark 16:9
} 
to tell the disciples that Christ has risen from the dead "...he goeth before you into Galilee, there shall ye see him ... and on their way to the disciples they meet Christ...they came and held him by the feet, and worshipped him." I In the Gospel of John, Mary Magdalene arrives at the tomb alone. "Early on the first day of the week, while it was still dark, Mary Magdalene came to the tomb and saw that the stone had been removed from the tomb." ${ }^{2}$ She then goes to tell Peter and John, who run to the tomb. Only after the men have left again does Mary encounter, not an angel, but the risen Christ himself. In the Gospel of Peter, Mary Magdalene and her friends arrive at the tomb early on Sunday morning. "Now at the dawn of the Lord's Day Mary Magdalene, a female disciple of the Lord (who, afraid because of the Jews since they were inflamed with anger, had not done at the tomb of the Lord what women were accustomed to do for the dead beloved by them), having taken with her women friends, came to the tomb where he had been placed." 3 As in the canonical Gospels they find the stone rolled away and the tomb empty. They are informed by "a certain young man seated in the middle of the sepulcher, comely and clothed with a splendid robe," 4 that Jesus is not there but has risen.

The significance of this act is that Mary Magdalene, being the first to witness the miracle of Jesus' resurrection raised Mary's status, for she was now referred to as the 'Apostle of the Apostles' as she was the one to bring the news of his resurrection to the other disciples.

Following the crucifixion, the disciples sank into despair: "How shall we go to the Gentiles and preach the Gospel of the Kingdom of the Son of Man? If even he was not spared, how shall we be spared?"5 Thus, in the wake of Christ's death, Christianity sank to its lowest point. At this nadir it would either have vanished or become just another marginal Jewish sect. It is doubtful whether the disciples would have had the courage to continue advancing the cause of Christianity without Mary. It was at this stage that Mary virtually takes over the leadership of the dispirited band and encourages and urges them to have faith: "Let us rather praise his greatness, for he prepared us and made us into men"6

If Peter's behavior leading up to the arrest of Christ, throughout the passion, and in its aftermath, is compared to that of Mary Magdalene's, and if we add that Mary's popularity and intimacy with Jesus easily overshadowed Peter's importance and authority, it seems a legitimate historical question to ask: why was Peter rather than Mary nominated to take over the leadership of the nascent Christian community?

According to the New Testament, the transmission of leadership was designated during Christ's lifetime and not after. Jesus had nominated Peter before his capture and execution. The stamp of approval is found in the biblical justification for this authorization as recorded in the New Testament, where Jesus says: "I tell you, you are Peter, and on this rock I will build my church, and the gates of hell shall not prevail against it. I will give you the keys of the kingdom of heaven, and whatever you bind on earth shall be bound in heaven, and whatever you loose on earth shall be loosed in heaven." 7

Yet from the historical perspective the authorization provided by this Christ-given statement remains suspect. First, can we be sure that the description of Peter's selection and his status as possessor of the keys of heaven as written in the New Testament was not added or amended later to justify his qualification? After all, the Gospels were composed, and the Canon was completed, well over one hundred years after the death of Christ. Second, it is noteworthy that two chapters further on to the 'keys' statement, in the same Gospel of Mathew, Jesus uses the

\footnotetext{
${ }^{1}$ Mathew Ch.28 v.7-9

2 John Ch. 20 v.1

${ }^{3}$ Gospel of Peter50-51

${ }^{4}$ Gospel of Peter 55b

${ }^{5}$ Gospel of Mary p.9: 8-9

${ }^{6}$ Gospel of Mary p.9: $16-17$

${ }^{7}$ Matthew 16:18-19
} 
identical words "...ye bind on earth shall be bound in heaven, and whatever ye loose on earth shall be loosed in heaven..." . Yet this time Jesus addresses all his disciples, and not just Peter. It can be deduced from this second usage of the identical words that they were intended as a general statement, and if so, surely this undermines the uniqueness and significance of the formula first spoken to Peter.

As already stated, female adherents were prominent among Christ's milieu, and it is accepted that Christianity's early maturation period held an egalitarian approach to the gender issue, considering it as an accepted norm in the early Christian Church ${ }^{2}$. Nevertheless, the vast majority of Jesus' disciples were males, and despite Mary's status and closeness to Jesus she was ensnared in the web of a male patriarchal society. With the passing of time, this patriarchal trend grew still stronger within the Church hierarchy, especially when Christianity was officially adopted as the sole legitimate religion of the Roman Empire at the end of the 4th century. Christianity now evolved into an integral part of western culture. Although within this religious-political-cultural matrix, women continued to strive for equality in virtually every field, men in their patriarchal hierarchy, held the upper hand. Consequently, by the early 6th century women found themselves stigmatized and demoted from almost all the major roles in the church service and liturgy.

The memory and heritage of Mary Magdalene took a corresponding blow. The veneration of the image of a charismatic woman at the pinnacle of the church hierarchy was not to be tolerated in this male-dominated culture. Mary's central role could lead to a situation where the status of women in the Church would be equal to that of men - or even to a woman becoming Christ's vicar on earth. In the eyes of the ruling Church elite, Mary had fulfilled her mission; her image had become not only superfluous but dangerous. Her memory was indeed threatening, as Mary, in her role as Apostle of the Apostles, who had empowered Christianity with the tools to persevere; and possibly could have superseded Peter in importance. Could she also engender a dynasty of women Popes?

Mary Magdalene would now become ousted from the Christian narrative, almost completely. Towards the end of the sixth century, in a Stalinist-style rewriting of history, Mary Magdalene was removed from her central position in the Western Christian matrix. The image and standing of Mary Magdalene that had developed in the early apostolic infrastructure was now considered undesirable. Like the swift fall of the guillotine, the role model of Mary Magdalene was severed from the axis of Christianity.

Fearing Mary's superiority over the Apostle Peter and her primacy in the Christian narrative, Pope Gregory the Great associated Mary's image with the unnamed 'harlot', mentioned in the book of Luke in the New Testament ${ }^{3}$, and in this way sought to discredit her with charges of human depravity and sin. Gregory proclaimed Mary's sexuality and beauty as a threat, which could undermine pure Christianity as formulated in the various ecumenical councils since the first one in 325 at Nicaea.

The 'putsch' took place in 591. Exploiting the textual vagueness of a number of rather ambiguous New Testament statements, Pope Gregory the Great labeled Mary Magdalene as a prostitute and sinner. In a dramatic ' $j$ 'accuse', Pope Gregorius 1, the Great, proclaimed in his homily 33, "She whom Luke calls the sinful woman, whom John calls Mary, we believe to be the Mary from whom seven devils were ejected according to Mark. And what did these seven devils signify, if not all the vices?"4

\footnotetext{
${ }^{1}$ Mathew Chapter 18 verse 18

${ }^{2}$ See footnote 3

${ }^{3}$ Luke: Ch. 8 v. 2

${ }^{4}$ Homily 33 is recorded in Homiliarum in evangelia, Lib. II, Patrologia Latina, vol. 76 (Paris: J.-P. Migne, 18441864), cols. $1238-1246$
} 
Rather than stressing Mary Magdalene's conversion to Christianity and attributes, he sought to identify her as the woman "out of whom went seven devils,". Once he had identified her as Mary Magdalene, Pope Gregory belittled the actual exorcism and the fact that Christ had claimed that her sins had been forgiven. Instead, Gregory deliberately identified and characterized her in her state of pre-converted sin. The church now made the most of the seven devils haunting her, by associating them with the seven vices considered directly responsible for the corruption of the human race. The devils or demons were considered sins. For the Church, Mary's pre-conversion state, in which she was afflicted with the Seven Sins, symbolized humanity's overall debased state of immorality. It now became the Church's mission to act to redeem humanity from this state and lead it to salvation. Thus, the central role of the Church involved creating an awareness of mankind's sinful state while offering up the hope of salvation. And salvation could only be obtained through the pursuit of Christian virtue and the acceptance of divine grace through the sacraments. The core message of Catholic Christian Orthodoxy resulting from this formulation was a clear statement that outside the One Universal Catholic Church there is no redemption. Mary's indictment as the unnamed sinner now legitimized her banishment from official Christian mainstream.

Pope Gregory went one step further: by associating Mary Magdalene with depraved sexual activity he was able to establish a direct link with female qualities of natural beauty and natural sexual appeal, and to claim that these qualities themselves were contaminated by sin. Of course, Gregory was not the first to take this attitude, for the compilers of the nascent Christian canon, a censorious attitude to beauty was unavoidably connected to the issue of women in general and their role in the Church in particular. For fourth- and fifth-century churchmen such as St. Ambrose of Milan and St. Augustine of Hippo it was quite clear-cut: feminine allure and sexuality were immersed in $\sin .^{1}$

The Church Fathers too were not saying anything new in their approach to sexuality, but simply following in the footsteps of St. Paul, who had reinforced his demeaning attitude towards femininity by identifying celibacy as the preferred state and virginity as the ideal - even though he did mutter something about it being better to marry than to burn. ${ }^{2}$

All in all, Pope Gregory succeeded not only in removing the female threat to the papacy but in forging a new and discredited female stereotype. The act of Immaculate Conception in the narrative of Jesus' birth was now elevated to an ideal of chastity, while sexual indulgence was frowned upon. And henceforth, for the next five hundred years, the enjoyment of sex was characterized as sinful.

Pope Gregory's interpretation was received as nothing less than the gospel truth. Henceforward, this depiction of Mary Magdalene (and the projected inferior female stereotype) became part of the Christian Canon throughout the Middle Ages. In doing so he ignored or downplayed the virtuous role of women throughout biblical history: among them exemplars of the Old Testaments such as Deborah the prophetess from Mount Tabor ${ }^{3}$; Miriam, Moses' sister who led the children of Israel out of Egypt in song and dance ${ }^{4}$; Lydia a seller of purple fabrics of the New Testaments ${ }^{5}$; and Queen Esther who saved the Jewish People in Persia ${ }^{6}$.

Pope Gregory's two-pronged attack on beauty and sexuality on the one hand, and on the status of women in the church on the other, had resounding consequences for the Christian world, for this was in complete opposition to the original Christian ethic. Women had figured prominently and very positively in Jesus' milieu and had been on an equal footing with men. Jesus had no

\footnotetext{
${ }^{1}$ Confessions of Augustine: Book 2

${ }^{2}$ Paul: 1 Corinthians 7:9

${ }^{3}$ Judges 4:6-7

${ }^{4}$ Exodus 15: 20-21

${ }^{5}$ Acts 16:24

${ }^{6}$ Book of Esther; in Writings (also called Hagiographa), the third section of the Hebrew Bible.
} 
qualms about treating even harlots in an egalitarian manner. Throughout the Gospels there are numerous instances of Christ's willingness to accept gifts and services from women. He interacted with them quite naturally and seemed to value their gentleness. In the Book of Luke alone, there are over twenty such references ${ }^{1}$.

By censoring Mary Magdalene Pope Gregory had cemented the theocratic basis for an exclusive dynasty of male popes. By abandoning Mary Magdalene Pope Gregory was intentionally leading the Christian world directly back to Eve - the symbolic mother of sinful mankind. Sin, vice and hell were now to predominate in the outlook of the Western world.

Between the 10th and 13th centuries of the High Middle Ages western Europe came out of its lethargy and took on new strengths. Among the evolving positive changes were a demographic increase in population, an improvement in climate, the resuscitation of cities together with the rise of the new merchant class, the birth of universities and the nascent maturation of national entities. The overall development in these numerous fields created a new tapestry of Europe, and the phenomenon is often referred to as the first Renaissance.

Despite the increasing absolute power of the papacy, the memory of Mary Magdalene was evoked anew. The history, myths and legends shaping her biography were retold and reinvented to intertwine among forgotten memories, and simultaneously she became adopted as the patron saint of numerous churches, convents and organizations. The question is, how did this now come about when her memory had been suppressed for some five hundred years?

On her departure from the Holy Land, Mary Magdalene's aim was to spread the Gospel, the 'Good News'. Tradition has it that her first destination was Italy, and of course - the heart of the pagan Roman Empire - Rome. Apparently, her daring and initiative enabled her to get a hearing with the Roman Emperor Tiberius (14-37 CE). She was probably listened to with interest, because she was, after all, Jesus' closest adherent, and an alleged actual witness to Christ's execution and resurrection.

Mary then waited in Rome for the Apostle Paul's arrival, and left some two years later. According to the sixth century historian, Gregory of Tours, Mary now went on to Ephesus in Turkey where she helped the Apostle John to compose part of his Gospel, spending here the rest of her life. One source claim that Emperor Leo Vl removed her relics to a monastery in Constantinople at the end of the ninth century. ${ }^{2}$

According to yet another legend, Mary Magdalene's remains reached Europe's western extremities - the British Isles. Allegedly, Joseph of Arimathea (who purchased Christ's burial plot in Jerusalem) was the one who brought Mary's remains to southern England and buried them in the crypt of the Glastonbury Abbey. ${ }^{3}$

The new spirit of the High Middle Ages produced numerous legends and romances. The Golden Legend, a hagiography of early Christian saints, composed by Jacobus da Varagine, includes the story of Mary Magdalene after Christ's death. This work presents a vivid narrative describing Mary's activities and biography beyond that of the known New Testament Christ story. The legend echoes the zeitgeist of the High Middle Ages, and gained popularity with the

\footnotetext{
1 The high standing of women in Luke's Gospel is evident from the beginning with two women playing enormously important roles in the history of salvation - Mary and Elizabeth, as well as Anna - roles which are described in such detail only by Luke 1-2. In addition, it is also evident that there is concern for widows in the Gospel; they are mentioned occasionally (Luke 2:37; 4:25-26; 7:12; 18:3; 20:47; 21:2).

${ }^{2}$ The Greek Church maintains that the saint retired to Ephesus with the Blessed Virgin and there died, that her relics were transferred to Constantinople in 886 and are there preserved. Gregory of Tours (De miraculis, I, xxx) supports the statement that she went to Ephesus.

${ }^{3}$ Origin in the Grail romances of the early Middle Ages. There was a Romance from around 1200 called Joseph Of Arimatheia, depicting him and his followers (not the Church) as Keepers of the Grail, never reaching Britain but founder of a secret Order whose members in the "vale of Avaron" knew the "secret" of the Grail -- the words which will end the "enchantment of Britain." The High History Of The Holy Grail, alias Perlesvaus, of c1225 $\mathrm{AD}$, and later Romances, even imply a dynasty from Joseph and Christ to Sir Galahad.
} 
renewed religious zeal surrounding the memory of Mary. This extraordinary tale evolved into a medieval best seller.

The Golden Legend claims that Mary was expelled from the Holy Land by the Roman authorities. together with a considerable party of friends and relatives: Mary Jacob, Jesus' Mother's sister who was James' mother, Mary Salome, the mother of the apostles James and John, Mary Magdalene's brother Lazarus and her sister Martha, their maid Sarah, Maximinus, one of the seventy-two disciples, and the formerly blind Cedonius, whose sight had been restored by Christ. This expulsion scene is depicted in the Basilica of St. Maximin in Provence, it is a beautiful low-relief gold-leafed woodwork centered on Mary as she steps into the boat. After having crossed the Mediterranean under Providence's guidance, Mary and her party of friends and relatives reached a safe haven on a coastal site close to the future bustling city of Marseille. On their arrival at Oppidum-Râ (as St Maries de la Mer was originally called), The Holy Land pilgrims did not receive a particularly warm welcome. In the mid-first century AD in France, or Gaul as it was then known, the region was very pagan. Furthermore, the xenophobic local residents refused to give them any form of succor. Eventually, Mary and her party found refuge in the porch of a pagan temple.

Here, in Provence, Mary found herself among a Romanized, cosmopolitan society holding a diversity of pagan beliefs. Although Mary's approach stood in stark contrast to the dominant pagan culture of her time, she also began to distant herself from the essence of her Jewish upbringing. Her Jewish roots posited the greatest emphasis on the here and now. Jewish culture stresses happiness and the 'joie de vivre', while Mary's soul-searching Christian doctrine viewed earthly existence as replete with sin.

Before long Mary Magdalene began preaching to the local inhabitants exhorting them to relinquish their idol worship and join the Christian community. Some of the pagans were soon baptized and converted to Christianity. Eventually, the community became organized within the framework of Christianity and Maximinus was appointed the first Bishop of Marseilles, to be followed after his death by Lazarus.

But Mary didn't stay put at St. Maries de la Mer. What triggered her departure? What motivated her to travel north to the Sainte-Baume Mountain range? According to the legend, after leaving Saintes Maries de la Mer, Mary Magdalene went north to the mountains of Sainte Baume, deep in the heart of Provence country. Here she continued her preordained mission to convert the region to Christianity. Mary Magdalene's final home was the Grotto of St. Baume.

The grotto is a vast empty dome carved from natural rock rising up several hundred feet. Water drips incessantly through numerous crevices. Today, a beautiful white altar stands out prominently and a number of shrines to Mary Magdalene dot the vast cavern. The cave is lit by a pale, weak light while the sun's rays radiate through a number of colored-glass windows. Here, in this cave, among the mountains of Sainte Baume, Mary is said to have retired and given herself up to a life of penance that lasted for thirty years. She converted the grotto of Sainte-Baume into her home, and here made penance for the sins of her early life style.

The point is that the significance of her acts supplied an essential spiritual core to the context of Christianity. Out of her actions, Christian charity, compassion and love, could be formulated. And her isolation in the mountains eventually evolved as a model for Christian monasticism. By not creating a communal monastic society, Mary probably became the forerunner of anchorite monasticism (individual habitation) for women, becoming a role model for Christian asceticism.

In the cave of St Baume, you can still view a magnificent reliquary supposedly containing a few remains of Mary Magdalene; a fragment of a tibia and a tuft of hair, although most of the relics were scattered during the French Revolution. The reliquary represents typical medieval craftsmanship at its best: a beautifully enameled metalwork casket fashioned in gold and ornamented with precious stones and gems. Small, delicately carved angels stand at the corners 
- perhaps suggestive of the seraphim which guarded the Ark of the Covenant, or possibly the two standing angels mentioned in Luke (Luke: 24:4) whom Mary meets on arriving at the empty tomb.

Angels are also mentioned as consoling and sustaining her with the food of the Eucharist for thirty years during her sudden disappearance into the mountains of Sainte Baume. Following her death, the story of Mary Magdalene's demise soon spread to Marseille: a local hermit reported that he had witnessed the scene of Mary in the arms of angels, ascending to heaven, singing songs of triumph. Like Mary the Mother, she too, according to Christian belief, was spared mortal death and was assumed to heaven. ${ }^{1}$ If so, we are presented with a paradox in that we are faced with an earthly tomb and remains.

Soon after the spread of the hermit's report, the Sainte Baume grotto, where Mary was believed to have settled in her sacred devotion to God, evolved into a holy site for Christian pilgrims.

If Mary Magdalene had evolved into such a prominent link in the triumph of Christianity during her lifetime it follows that she had to be worshipped after her death too. Yet at what spot, gravesite? Where did her followers assemble to commemorate her memory? Where were her remains interred apart from a few body parts in the cave of St. Baume? Were there other memorial sites? The answer to this question lies not far from St. Baume, it is in the neighboring town of St. Maximin, which is a charming ancient Gallo-Roman township, and evolved into one of the first centers of early Christianity in Provence.

Except for Magdala, Mary Magdalene's town of birth in the Holy Land, Saint Maximin is the only town in the world whose renown and attraction are anchored entirely in the legend and history of Mary Magdalene. For it was here that Mary's remains were supposedly laid to rest. Having received the last rites from Maximinus (the later St. Maximin), she was buried here and the site has since become a center of pilgrimage.

The Basilica of St. Maximin lies at the foot of the Sainte Baume mountains and is situated forty kilometers east of Aix-en-Provence. ${ }^{2}$ Nestling high up on a hilltop overlooking the town, the church stands majestically, shining bright in the morning sun. Its grand size and thirty-threemeter height make it the highest church in Provence - and it is visible from every angle.

In the deep ancient crypt, there are four marble sarcophagi. Three of the sarcophagi hold the remains of saints, including Saint Maximin. And the fourth, the remains of Mary Magdalene! The plaque above Mary's sarcophagus states: "Mary Magdalene was buried in the crypt just after having received communion from the Bishop Maximin." At the rear of the cavernous sarcophagi niche the golden shrine of Mary Magdalene stands prominently behind a thick glass partition. A dark skull-like death mask set in gold, peers at you. The skull, veiled by the mask, is alleged to be that of Mary Magdalene and is graced by two small exquisitely sculpted angels. A musty smell redolent of hundreds of years of decrepit human bones suffuses the air. The relics of Mary Magdalene continue to attract considerable numbers of visitors and pilgrims to the Basilica from near and far. On July 22 of each year, Mary Magdalene's Saint's day, an impressive procession takes place here and the cranium is covered by a golden mask.

Mary the Mother has no grave - as she did not die a mortal's death - and the apostles John and Paul have no identifiable burial sites. It's generally accepted that the Church of the Holy Sepulcher in Jerusalem, where Christ was crucified, and the Church of Saint Peter in Rome, where the first pope was buried, are the two most famous Christian tombs. St James' tomb at Compostella, is often considered as the third in importance, but as there's no consensus in this matter, it's reasonable to assume that the third most important tomb could be the Basilica of Saint Maximin, where Mary Magdalene is buried. After all, as stated, Mary Magdalene was

\footnotetext{
${ }^{1}$ According to The Golden Legend, seven times a day angel carried her aloft to heaven, where she glimpsed her coming reward. This scene of ecstasy arose during the Counter-Reformation and became represented in Baroque art as a medium to emphasize the veneration of saints.

${ }^{2}$ The following description is detailed in: Shapiro. F, Eve and Mary, Axis Mundi Books, 2014
} 
Christ's most intimate companion, and the first of his devotees to actually see him resurrected, and by bringing this news was named the Apostle of the Apostles. Mary then went on to instill hope and to encourage the other followers to continue with Christ's work.

The Basilica of St. Maximin, which was built twelve hundred years after the death of Mary Magdalene, was founded by Charles II d'Anjou in 1280 and dedicated to Mary's honor and glory. Built over Mary's remains, the basilica received the blessing of Pope Boniface VIII and the right to hold her relics.

In Italy, at the Scrovogni Chapel in Padua and at the Church of St. Francis in Assisi, the wonderful creations of the Florentine artist Giotto di Bondone (1266 - 1337) can still be viewed in full clarity. His works are more than artistic creations; they are detailed, realistic narratives providing us with full cycles of biblical stories. Distancing himself from the two-dimensional Byzantine tradition, Giotto revolutionized painting in Western Europe. Executing his works in the mediums of fresco, sculpture and mosaic, Giotto received commissions to adorn palaces and churches. Triggering a return to representational and three-dimensional art he affected the entire art movement in Western Europe, and in doing so paved the way for the Renaissance. Giotto's art also played a part in the rehabilitation of Mary Magdalene by painting the amazing legend we have been following of Mary Magdalene and her journey to southern France. ${ }^{1}$

Giotto was not alone in the artistic restoration of Mary Magdalene. The new spirit of the High Middle Ages also finds expression in the illustration of medieval literature. One example is that of the Psalter - a medieval religious book comprising mainly psalms. The St Albans Psalter, also known as the Albani Psalter, is an English illuminated manuscript, one of several Psalters known to have been created at or for St Albans Abbey in England in the 12th century. Here one can see a depiction of Mary Magdalene relating her witnessing of the reincarnation of Christ to the other disciples. An assortment of human personalities radiates through a spectrum of colors.

Donatello, the early Renaissance artist, perhaps expressed better than any other, the convergence of Christian and secular values. In his extraordinary sculpture of a realistic aging Mary Magdalene, ${ }^{2}$ Donatello made his artistic and humanistic statement in perceiving the saintly Mary Magdalene's renewed centrality in the human drama here on Earth. Donatello attributed her importance to the age of Humanism. The ethos of compassion and empathy as embodied in this creation embraces the very essence of Humanism.

The military Order of Knights Templar, whose name originates from the fact that they set up their first headquarters on the Temple Mount in Jerusalem, was established to protect the Christian pilgrims and the Christian holy sites in Jerusalem. It also dedicated itself specifically to the memory and qualities of Mary Magdalene. In Mary's image, they saw all the virtues they most admired. Naming her the patroness of their Order, they honored her Feast Day on the 22 July by saying special prayers in her memory.

A plethora of guilds, chapels and institutions now honored Mary as their patron saint. Fairs, festivals and various sites were named in her honor, and important church services and prayers were conducted in her memory.

Thus, by the mid-thirteenth century, the image of Mary Magdalene was once again very visible and significant in a myriad of aspects of the medieval religious-political matrix.

Symbolically, Mary Magdalene's revamped image was akin to a bright light signifying greater spiritual freedom. It was symbolized by the natural light now penetrating the magnificent multicolored windows of the huge Gothic churches and palaces, sprouting across town and countryside.

\footnotetext{
${ }^{1}$ Scenes from the Life of Mary Magdalen: 1320s, Fresco Magdalen Chapel, Lower Church, San Francesco, Assisi

${ }^{2}$ Museo dell'Opera del Duomo, Florence
} 
In the secular domain, the spiritual and emotional messages of Mary Magdalene have resulted in this artistic inspiration in the visual arts and so inspired generations of artists, particularly since the Renaissance. Hundreds of years later, this impact resurfaced to become a major theme in the Romantic Movement. Today Mary Magdalene's multidimensional image has become an accepted major figure in the western cultural and spiritual matrix.

\section{Conclusion}

Whatever elements of historical accuracy can be filtered out of the intricacies of the myths and legends in this narrative, the point is that in reality the import of these accounts is considerable. Assorted Christian movements and sects ardently evoked Mary Magdalene's influence on Christianity, and subsequently on western civilization. The Order of the Dominicans not only believed in the sources of Mary's earlier life, but accepted much of the legend's content as well, and promulgated their beliefs accordingly. In the main, the Dominicans viewed Mary Magdalene as a penitential model seeking repentance. ${ }^{1}$ The Evangelical movement also claimed Mary's significance and viewed her as a model inspiring hope and as an exemplar of a soul in love with God. ${ }^{2}$ All these devotees see in the penitential Mary Magdalene as proof of one's potential to rise to the peak of intimacy with God after having sunk into the lowest depths. Finally, in 1969, Pope Paul Vl cleared Mary Magdalene's name by declaring that she was not the harlot and sinful woman as written in Luke and identified as such by Pope Gregory the Great. On June 3 2016, Pope Francis, went even further by enhancing Mary's status in his announcement that the memorial day for Mary Magdalene is to be elevated to a major feast day to be held in her honor. ${ }^{3}$ According to Lucetta Scarrafia, editor of the Vatican-published Women Church World monthly magazine, "By doing this, he (Pope Francis) established the absolute equality of Mary Magdalene to the apostles, something that has never been done before and is also a point of no return for women in the church".

Yet the paramount point is, that it is doubtful whether Christianity could have survived without Mary Magdalene. So surely Mary Magdalene can be ranked as one of the most significant personages in Christianity.

\section{References}

Gospel of Mary 17: 9-20: “Gospel of Mary Magdalene” Inner Traditions.2002

Gospel of Peter: http://www.earlychristianwritings.com/text/gospelpeter-brown.html

Gregory of Tours (De miraculis, I, xxx) (Paris, 1913), xx-xxx

McKnight S, "The Mary We Never Knew". Christianity Today. 2008

New Testament in Holy Bible, King James Version Zondervan, 1983

Ibid: Romans:16

Ibid: Book of Mark 15-4-41

Ibid: Book of Mathew 27.55-56

Ibid: Book of Luke 8.1-3

Ibid: Book of John 4-9.27

\footnotetext{
${ }^{1}$ In 1295, the Dominican Order was given care of the Shrine of St. Mary Magdalene at Le Sainte Baum (the Holy Cave), in southeastern France...from the beginnings of the Dominican Order, she was proclaimed co-patroness of the newly founded apostolic Order of Friars Preachers.

${ }^{2}$ Scot McKnight. "The Mary We Never Knew". Christianity Today. Retrieved 2008-05-07

${ }^{3}$ https://www.vaticannews.va/en/saints/07/22/st--mary-magdalene--disciple-of-the-lord-.html
} 
Ibid: Book of Acts

Ibid: Paul 1: Epistle to Corinthians, Phil. 4.2

Old Testament in Holy Bible, King James Version Zondervan, 1983

Ibid: Book of Exodus, Ch.15

Ibid: Book of Judges, Ch.4

Ibid: Book of Esther; in Writings (also called Hagiographa), the third section of the Hebrew Bible

Patrologia Latina, Homily 33 Lib. II, vol. 76 (Paris: J.-P. Migne, 1844-1864), cols. 1238-1246

Saint Augustine, Confessions of Augustine: Book 2: https://www.gutenberg.org/files/ 3296/3296-h/3296-h.htm

Shapiro F, Eve and Mary, Axis Mundi Books, 2014

Varagine Jacobus da, Legenda Aurea, Biblioteca Medicea Laurenziana, Florence, 1290 circa

Vatican News: https://www.vaticannews.va/en/saints/07/22/st--mary-magdalene--disciple-ofthe-lord-.html 